\title{
ERRATA
}

Transfer of Thermus ruber (Loginova et al. 1984), Thermus silvanus (Tenreiro et al. 1995), and Thermus chliarophilus (Tenreiro et al. 1995) to Meiothermus gen. nov. as Meiothermus ruber comb. nov., Meiothermus silvanus comb. nov., and Meiothermus chliarophilus comb. nov., respectively, and emendation of the genus Thermus

M. Fernanda Nobre, Hans G. Trüper and Milton S. da Costa

International Journal of Systematic Bacteriology (1996), 46, 604-606.

p. 605 , the collection number for the type strain of Meiothermus ruber is 'ATCC 35948' not 'ATCC 37498'

\section{Thermococcus fumicolans sp. nov., a new hyperthermophilic archaeon isolated from a deep-sea hydrothermal vent in the North Fiji Basin}

Anne Godfroy, Jean-Roch Meunier, Jean Guezennec, Françoise Lesongeur, Gérard Raguénès, Alain Rimbault and Georges Barbier

International Journal of Systematic Bacteriology (1996), 46, 1113-1119

p. 1118, the collection number for the type strain of Thermococcus fumicolans is 'CIP 104690' not 'CIP 104680'

\section{Bacillus horti sp. nov., a new Gram-negative alkaliphilic bacillus}

Isao Yumoto, Koji Yamazaki, Tomoo Sawabe, Kazuaki Nakano, Kosei Kawasaki, Yoshio Ezura and Haruo Shinano

International Journal of Systematic Bacteriology (1998), 48, 565-571

p. 567 , column 2 , line 2 should read 'Whole-cell fatty acids of strain $\mathrm{K} 13^{\mathrm{T}}$ consisted of the straight saturated fatty acids $\mathrm{C}_{10: 0}(0 \cdot 4 \%), \mathrm{C}_{14: 0}(0 \cdot 4 \%), \mathrm{C}_{16: 0}(1 \cdot 1 \%)$, and the monounsaturated $\mathrm{C}_{16: 1}(1 \cdot 9 \%)$. Branched saturated fatty acids included iso- $\mathrm{C}_{14: 0}(2 \cdot 4 \%)$, iso- $\mathrm{C}_{15: 0}(38.4 \%)$ and anteiso- $\mathrm{C}_{15: 0}(30 \cdot 2 \%)$, iso- $\mathrm{C}_{16: 0}(4 \cdot 4 \%)$, iso-C $\mathrm{C}_{17: 0}(5 \cdot 3 \%)$, and anteiso- $\mathrm{C}_{17: 0}(3 \cdot 2 \%)$. Branched monounsaturated fatty acids included iso- $\mathrm{C}_{16: 1}(4 \cdot 4 \%)$, iso- $\mathrm{C}_{17: 1}(5 \cdot 5 \%)$ and anteiso- $\mathrm{C}_{17: 1}(2 \cdot 0 \%)$.' not 'Whole-cell fatty acids of strain $\mathrm{K} 13^{\mathrm{T}}$ consisted of the straight saturated fatty acids $\mathrm{C}_{10: 0}$ $(1.2 \%), C_{16: 0}(1 \cdot 1 \%), C_{17: 0}(1.9 \%)$, and the monounsaturated $\mathrm{C}_{16: 1}(5 \cdot 3 \%)$. Branched saturated fatty acids included anteiso- $\mathrm{C}_{14: 0}(2 \cdot 4 \%)$, iso- $\mathrm{C}_{15: 0}(38 \cdot 4 \%)$, anteiso- $\mathrm{C}_{15: 0}(30 \cdot 2 \%)$, iso- $\mathrm{C}_{16: 0}(4 \cdot 4 \%)$, anteiso- $\mathrm{C}_{16: 0}(4 \cdot 4 \%)$, iso- $\mathrm{C}_{17: 0}(1 \cdot 4 \%)$, and anteiso- $\mathrm{C}_{17: 0}$ plus unknown fatty acid $(7.9 \%)$.' 